\title{
Information Support for Academic Administrators: A New Role for the Library
}

\section{Peter G. Watson and Rebecca A. Boone}

The concept of a direct information support service for academic administrators by librarians is presented. The costs and benefits of such an undertaking are discussed, and the results of a test are reported, together with the model and rationale for a service. The test supported the hypothesis that demand for this type of service does exist, once administrators are apprised of the possibility for it, and that they are highly pleased with the results and with the librarians for offering it. The paper concludes with a presentation of issues in library service, technique, and philosophy that were identified during the test.

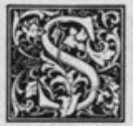

everal recent authors, most notably Charles Martell in The Client-Centered Academic Library, ${ }^{1}$ have explored the concept that the actual needs of user groups could influence the design and organization of library services much more than they have in the past. One obvious example is the fee-based services designed as a response to pressures from noninstitutional groups (especially business and industry) for improved access to their local academic library. Another is the emergence of document delivery systems on campus, usually directed toward faculty and organized research teams. This paper discusses a further example of clientcentered service in the college or university library, namely, a library/information support service for administrators. Our working hypothesis is that it would be a benefit to both the academic library and its parent institution for the library to provide a specialized, direct, information support service to identified senior administrators of the college or university. We will present a rationale and a model for such a service and identify some of the benefits, costs, and major procedural, service, administrative, and professional issues involved.

Online and manual literature searches produced only one document squarely on this topic: a SUNY-Buffalo library proposal (1973) that was not implemented. ${ }^{2}$ The following exposition, therefore, stems largely from our discussions with administrators, our experience as library public service managers, and an in situ test of the basic concept.

\section{RATIONALE FOR ESTABLISHING A SERVICE}

A small test by one particular library is useful but may not by itself provide the necessary professional foundation that would enable other libraries to develop this new concept in their own operating

Peter G. Watson is University Librarian, Idaho State University, Pocatello, Idaho, 83209-0009. Rebecca A. Boone is Associate Dean at the College of Arts and Sciences, University of Arizona, Tucson 85721 (on leave, 1988-89, as Administrative Intern, Arizona Board of Regents, Phoenix, Arizona 85012). The authors wish to thank Judith A. Sessions, former university librarian, and Frederick W. Ryan, former deputy university librarian, California State University-Chico, for their administrative and professional support of the test. 
environments. In this section, therefore, we attempt to provide a wider professional framework for having the academic library serve administrators, a rationale that has general applicability.

1. As part of the broad-based movement of the modern profession of academic librarianship toward an active service posture, librarians are looking afresh at the needs of their client groups and devising strategies and products to meet those needs.

Like many service institutions, the library is being modernized while its essential continuity of function and purpose is being maintained. Banks, for example, have recently developed a whole series of new services segmented toward specific groups. So, too, have academic libraries begun to provide students and faculty with such innovations as computerized literature searching, bibliographic instruction, fee-based information services, and document delivery. Academic librarians should give serious thought to extending this approach to another group that also has demonstrable need for useful, effective information support: namely, the campus administration.

2. Campus administrators are almost exclusively drawn from the teaching and research faculty ranks and are not fully aware of the library's potential for supporting administrative work.

The faculty, including those who move into academic administration, are the "core group" in the management of any college or university. ${ }^{3}$ In terms of their need for, and use of, information services, the faculty can occupy a surprisingly large number of different roles, of which this paper examines just one, that of academic administrator. ${ }^{4}$

Even though academic administrators are not actively teaching, they retain the typical faculty relationship with the library, its resources, staff, and services: namely, a solitary interaction between themselves and the materials that embody their area of research., Their view of libraries and librarians has not changed as their administrative responsibilities (which may even include the library) have evolved. What this will often mean, in practical terms, is that the administrator still knows and uses libraries in only one way-by paying a personal visit, consulting a few tried and trusted sources, browsing the stacks, and in general doing everything directly, for oneself, by oneself. After all, as a scholar, one is expected to know the library, and not to have to ask for assistance.

The academic disciplines are the basis for the organization and services of academic libraries and for the faculty member's interaction with them. But the disciplines do not constitute an easy key for addressing administrative concerns such as how other universities are responding to political pressure to change the balance between teaching and research functions or what faculty salary and benefit structures are used in peer institutions. Administrators are seldom seeking pure research or a sequence of analytical or interpretive articles in periodicals; they are much more likely to require applied research, current policies and procedures from other institutions, and raw data brought together into a useful whole.

In addition, administrators will often simply lack the time to walk over to the library and embark on a lengthy search for information. If the scholar turned administrator cannot find the needed information fairly quickly in person, or at most with an occasional question to a reference librarian, the information is probably not going to be pursued within the library. The library as an information system quickly becomes functionally unusable; administrators have simply accepted the idea that the library (as they conceive it) is not a tool used for administrative purposes.

3. Those who administer the complex corporate structure of the modern college or university need and deserve more active, relevant, information service support from the library, and the library is now much better equipped than, say, fifteen years ago, to respond vigorously to such a challenge.

Academic administration has become much more information-dependent for the fulfillment of many standard administrative tasks (planning, coordinating, 
evaluating, decision making, etc.), while concurrently the information service capabilities of academic libraries have expanded enormously. For our present purposes this is most strikingly evident in two broad areas-the computerized searching of bibliographic, numeric, and even fulltext databases and the electronic tying together of the nation's system of interlibrary cooperation. Other advances in modern librarianship also contribute, such as the advent of the online catalog, enabling access to a library's holdings from home or office, not merely from within the library walls.

4. As an institution, the academic library is under considerable strain and requires its own well-informed support base on campus.

Partly due to the very success of their new, electronically based systems for retrieval and access, many academic libraries are experiencing a surge in the amount and intensity of demand. At the same time, they are constrained to operate with budgets that are functionally much tighter than a decade ago. Higher-thanaverage inflation of book and journal prices, higher salaries, the need for largescale automation-these and other unavoidable cost components all take their slice of the budget, often leaving little true discretionary money in the hands of the library director.

This part of the rationale sounds like a reason not to start a new service, rather than the reverse. But the library is in acute competition with other campus agencies for dollars and (equally important) for administrative support. Its role as a necessary service for most faculty and students does not give it a built-in claim on the attention of administrators. Provision of a direct, personal service to those administrators might enlarge and enhance the library's institutional position and role in their minds, at the same time increasing its relevance both to themselves and to the college or university as a whole.

\section{Costs}

\section{COSTS AND BENEFITS}

Obviously there will be costs associated with any new service, especially in libraries that already feel stretched just to stay in control of their existing workload.

Regardless of size or type of library, the main cost components will include:

1. Librarian time

2. Support staff time

3. Online searching

4. Document procurement (copying, ILL, mail, etc.)

5. Supplies and other miscellaneous operating expenses

Additionally some libraries will need to account for:

6. Opportunity cost (of resources diverted from other tasks)

\section{Overhead}

The California State University-Chico (CSU-Chico) test (described below) was performed at relatively low cost. Of the four types of direct costs that could be identified in advance (computer searching, photocopying, interlibrary loan charges, and mail and long-distance telephone), only the first two materialized during the test: computer searching averaged $\$ 12.44$, and photocopying averaged $\$ 3$. Total staff time per question was about one hour (roughly estimated as forty-five minutes of librarian time, fifteen minutes of support staff time). Librarian time was calculated from initial consultation to presentation of results. The time taken to explain the purpose and scope of the test on the initial visit is not included in this, because it is dependent upon the interests of both the administrator and the librarian.

We estimate that the inclusion of labor costs would add $\$ 15-20$ to the transaction cost, at current rates for an upper-range librarian and a middle-range paraprofessional.

Costs for supplies and other miscellaneous operating needs were negligible. Overhead and opportunity costs were not computed but would be institutionspecific.

Within this framework, the total identifiable cost of providing the service appears to be about $\$ 30-35$ per question-probably very close to the cost of other types of indepth library service offered on a limited scale. 


\section{Benefits}

In assessing what benefits there are and could be, we believe it is important to recognize (a) that this is a service whose benefits should be viewed strategically rather than tactically; (b) that the actual costs may not be very great overall, and the benefits will likely be substantial; therefore (c) that in terms not just of cost or benefit, but of the cost-benefit relationship, this may turn out to be one of the most valuable initiatives the academic library could decide to undertake. Thus the discussion of costs and benefits very quickly becomes a reassessment of library priorities.

\section{Benefits to the Institution}

Better informed administrators. Suppose that administrators can use the library effectively: in most cases, they would rather not have to do this, and a librarian could probably do it better. At the very least, therefore, the benefit here is precious time saved for the administrator. More often, we believe, having the library undertake this service will provide an improved information flow to administrators, as well as saving them time.

Better administrative performance. Among the important functions that can be assisted by a better foundation of information are planning; decision making; establishment of mission, goals, and policies; program evaluation; use of funds; compliance with legislation; development of grant proposals, etc.

We emphasize that a library support service for administrators is by no means a panacea; it will not create good administration where such does not exist, any more than solid information support for scholarship will create good scholarshipbut, as is true with scholarship, there will be a better chance of good performance if there is an improved level of information support. Erroneous or unproductive courses of action can be avoided, and particularly suitable or relevant solutions from outside can be more speedily evaluated and adopted. The universally shared aim of achieving the best administrative practice can be brought substantially closer to realization.

More effective fulfillment of the institution's academic mission. Although the institutional mission statement is usually a broad, sweeping generalization of intent, it does embody the college or university's definition of itself. Better informed administrators can participate more fully in the institution's various activities, leading to a more comprehensive realization of the mission statement. They can, for example, uphold the institution's position more effectively in outside forums if they are given the appropriate facts, figures, or analyses in advance.

At the institutional level, the teaching, research, community service, and other components of academic life blend together. It is our belief that, in time, the existence of such a service will be assumed, and its regular use taken for granted, and that this in turn will contribute strongly to a greater cohesiveness in the college or university's response to mission-related matters.

Better administration of the library by college or university officers. Closer involvement by senior administrators in the life of the library will enhance their awareness of its needs, goals, and problems.

Along with this will come an awareness of the overall interrelationship of various campus information services (usually the library, computer center, and instructional media)-thus giving fresh impetus to increased administrative coordination among them. This too can be useful to the library in mutually clarifying roles and missions with those agencies, to which any academic library is nowadays inextricably linked in the provision of information service to the institution.

\section{Benefits to the Library}

A more informed appreciation by senior campus administrators of the professional role and skills of the librarian as an information specialist. One result should be a better administrative understanding of the rigor, imagination, scholarship, logic, experience, judgment, and knowledge of the field that the good public service librarian brings to bear upon the complicated, ever-changing modern world of information production and dissemination. This could be invaluable, for example, 
when librarians are reviewed for retention, tenure, promotion, merit awards, sabbaticals, etc. Unobtrusively assisting administrators to experience, or "get a handle on" the modern academic library, will lead to administrators who are much better informed about the library, who can empathize more with the dynamics of library management, and who henceforth can speak with more authority in campus or external discussions about the importance of information, libraries, resources, and even national agencies such as LC, OCLC, and CRL. This is to the library's advantage.

$A$ better image for the library and thus an improved climate of support for the library. Administrators want very much to be proud of "their" library, and usually are. The high immediate impact of a direct support service from the library will give them an additional reason to be so. Administrators will welcome library initiatives that fit with their concepts of the institution's goals and needs. Among one administrator's initial reactions to the pilot test was the interesting observation that he appreciated this effort to utilize the library "to the full"--even though, as far as we know, the idea of the library doing this had never before occurred to him.

As regards actual procurement of funds, just starting to provide administrators with information support may well raise the possibility of new sources of funding for the service itself, such as an increase in the library budget to enable the service to continue. Or it could help foster an improved climate of support for some quite different long-term needs of the library, such as a new building, or an across-theboard increase in the materials budget.

Increased utilization of the librarian's time on clearly professional tasks, assuming that any tasks that must be deferred, transferred, or abandoned, will be 'low end' tasks of marginal professional content, merely things that the librarian was doing because it was felt someone had to do them.

Enhanced self-image of librarians as professionals. We believe that any time librarians work directly with senior campus administrators, they will perceive themselves as contributing significantly to the life of the institution and should experience higher self-esteem thereby. A parallel to this is the rise in professional self-esteem that took place among academic reference librarians all across the land ten to twelve years ago as they assumed the role of computerized search specialists and began to work more directly with the faculty's information needs.

\section{MODEL OF A LIBRARY/ INFORMATION SUPPORT SERVICE FOR ADMINISTRATORS}

The basis for the series of steps that comprise this model is a test conducted by one of the authors during the 1986-87 academic year at CSU-Chico.

1. The library administration first agrees to devote some of its personnel and other resources to the direct, immediate support of information requests made by senior academic administrators.

2. The library decides upon at least one librarian who will perform the initial service. The persons selected must be:

(a) equipped with up-to-date skills in general reference service, including the ability to perform computerized literature searches on a broad range of topics, especially higher education;

(b) well respected outside the library and fairly senior in terms of rank and service on the campus;

(c) able to cultivate a continuing confidential relationship with campus administrators;

(d) able to maintain flexibility in their schedules.

3. The library director sends a letter to, or meets personally with, a small number of senior administrators, introducing them to the general idea and inviting them to participate. It is advisable also to emphasize that the library realizes that each person's information needs are private, and that confidentiality will be closely guarded. We suggest a small group of administrators to begin, so that the library can acquaint itself with the dynamics of such a venture before any large-scale public commitment is made, and we suggest senior administrators simply in recognition of good campus politics and greatest unmet need. 
4. The participating librarian is then assigned to cover four to six administrators, no more. A general allocation of time in which to perform the service should be agreed within the library in advance. About two hours per week is suggested as an average.

5. The librarian visits the offices of those administrators in her or his group, explains the concept and the general procedures, and, as soon as the administrator begins to respond, takes notes with old-fashioned paper and pencil. Tape recorders are not recommended-they will inhibit freeranging conversation, which is one of the most valuable communication devices in operating this type of a service. The Chico test revealed at an early stage the value of listening for unstated, implied needs or concerns, in addition to the overt topic of the information request. Any time administrators talk more than briefly about a work-related matter, it is likely that they are thinking through a current problem or situation (perhaps an issue from an immediately preceding meeting) and that some ingenious information support, provided before it was even formally requested, would be a welcome surprise. The librarian's unstated approach should not be "What is the question?" but "What's on your mind?" It is also worth recognizing from the outset that busy administrators are not going to consent to be served if there is the penalty of filling out a form, so no effort should be expended in designing one, nor should the client be constrained to deal with existing library forms (e.g., for a computerized search, or for microform copying). This is indeed a type of service which, if it is to stand any chance of succeeding, must go significantly beyond the traditional nodus operandi in which the librarian starts users off, then leaves them to do the rest. The librarian has to be committed first and foremost to delivering a product that is usable and must therefore be willing to remain flexible enough to employ procedures that will contribute to this end: to follow the opening offer of service with "Sorry, but the library does not do (has never done) that" obviously will not gain the library much credit with senior administrators.
6. The librarian carries out the search. This will normally involve analyzing the question (including checking the meaning of terms where necessary); identifying sources; performing a computerized literature search if appropriate; and obtaining selected documents from the library's collections. High priority should be given to making photocopies for the administrator to retain, where allowed and appropriate, and to requesting other needed documents from a remote source (via ILL, or, more innovatively, via phone to a human source).

In the pilot test, responses to the request usually took one of two forms:

1. photocopied pages of the needed material with pertinent sections marked with a highlight pen, or

2. a specially marked printout from a computerized search, inviting the administrator to check off any citations that looked interesting, and returning the list to the library so document procurement could begin.

After two months, the evidence began to suggest that the latter was not, by itself, sufficient, as no administrators returned their list for document procurement to begin, although in at least some cases, the extensive ERIC abstracts were sufficient.

The main reason for not immediately proceeding to search out and send the documents cited in a computer search was the newness of the venture, and the librarian's initial unfamiliarity about which of the citations would be highly pertinent to the need, and which would not. As a longer cooperative relationship developed, both the administrators and the librarian came to expect that the latter would routinely employ professional judgment and select the most useful material without very much risk of being wildly wrong or of raising concerns about exercising censorship.

Incidentally, the CSU-Chico library does not have a formal document delivery service, but it was apparent from the outset that for the test to have any real utility, an ad hoc process of document delivery would have to be built in. The only alternative would have been to adopt the timehonored library posture of assuming that 
the users would walk over to the library, find for themselves any materials they wanted, and be sure to bring their library cards, and their wallets (or an account number). This was unacceptable, for the reasons discussed earlier.

7. For purposes of continuity (e.g., possible follow-up of questions or billing of charges), as well as for program assessment, basic records are kept by the librarian. Similar in scope and level to records kept for other types of personalized library service such as ILL or computerized literature searching, these should show the nature of the question, date received, date needed, sources consulted, time spent, and levels of personnel involved. It is desirable for entries in the log to be arranged in simple numerical order. The designated librarian can maintain his or her own cross-index showing which administrators asked which questions. An example, using a log sheet for reference transactions derived from California's North State Cooperative Library System, is shown as appendix A. Note that this is a $\log$ of the search and retrieval processes only, and does not reflect total project activity.

8. After a suitable period, say one academic year, a brief evaluation is performed. The reason to keep it brief, resisting the temptation to ask all conceivable questions that it might be useful to have answered, is that busy administrators generally do not respond well to long questionnaires. The cover letter needs to be tactfully phrased as a request for assistance and should express appreciation for the respondent's time, etc.

\section{Reactions to the Test}

The details of the test results have been reported elsewhere. ${ }^{7}$ There was nothing very remarkable or innovative about the actual searching. The librarian merely did for the requesters what he would have done for himself, had the questions been his own: find the information. He searched through some secondary sources, identified some relevant-looking primary sources, and obtained working copies thereof. Incidentally, we found it significant that in not one case out of the fifteen undertaken was the end result a book checked out of the library.

We feel it important to convey to library managers and administrators the warmth and enthusiasm with which the idea, and the test itself, were received. In a word, the recipients were ecstatic (their term, on more than one occasion). Within an hour of receiving the announcement, the university president was on the phone; then the vice-provost submitted a question. The provost immediately wrote a highly laudatory note praising the general concept, and later sent another one expressing appreciation for information delivered. The vice-president for student affairs said she had several likely topics we could utilize. The president, after using the information from his first request in a public debate that was locally reported and broadcast, then presented some other questions. In a little less than two semesters, fifteen questions were handled from four administrators of the six originally approached, and from two of their principal subordinates.

The provost, into whose area of reporting responsibility the library falls, later expressed specific interest in exploring the potential of the library as an administrative support tool, and asked the librarian to give a presentation about this (as yet nonexistent) service to the dean's council. He voiced his concern that administration was often performed on a too-narrow base of information, and that the library might assist not only in its own right but also as a coordinating agency for improving administrative access to the myriad other sources which we all know exist on campus-enrollment data, planning information, institutional research findings, etc. One generally didn't go over to the library with these administrative information needs, he added. First, one didn't have the time, and second, one was reluctant to put more work on the librarians. The test demonstrated that this reaction is fairly typical, and perfectly sensible, from a senior academic administrator.

\section{ISSUES}

Any library embarking on this type of service can expect many new and fascinat- 
ing issues of library service to be raised, and to be debated con brio among the librarians. The issues will span the range from philosophical to technological, from organizational to logistical. Among the more substantial ones unearthed by our initial test are the following:

1. The library's role. Should the library be providing this level of service? Apart from the practical considerations (the burden of time and expense) should we not also ask whether the role of personal information specialist is one that the librarian can or should play? Will not administrators, like other clientele such as students, be better served by seeking their own information in their own way, without a third party, which inevitably leads to less than perfect transmission and communication?

This issue has a certain theoretical validity, but in practice most people simply cannot be, nor are they willing to be, their own information specialists. Doubtless there will always be those few who can and do perform this role for themselves, but the vast majority of scholarly and professional people are more in need of the highest available level of information support than ever before. If there is some loss in information because of transmission through an intermediary, it appears to us to be minor and easily surmountable, given high-quality performance by the information professional.

2. Time per question. Can this level of service be sustained and built into normal library operations? The time commitment required for each question is substantial; forty-five to sixty minutes seems to be usual, and two hours should be expected occasionally. There will be only a relatively small number of questions submitted in any given month, so that with some rescheduling of regular tasks the overall burden on the librarian is not drastic. Also, one might ask, "What are the professional librarians doing with their time that can be shown to have equal benefits for the library? Can some tasks be transferred to a competent library assistant? To a secretary or even a student assistant?"

3. Sources. Among the more crucial library resources for support of such a ser- vice are government publications, online searches, printed reference sources, college catalogs, university archives, and state and federal laws and regulations governing higher education. One must, in addition, be willing to go a little further afield. This could include contacting other people on campus or in the local community; calling other colleges and universities for comparable data and asking those institutions to send by express mail some internal document, charged to the receiving library's account; and/or signing on to BITNET or some equivalent electronic network for the academic community.

4. Continuity of personnel. Given the shorthand with which most people speak (and many of these information requests will come via the spoken word), it is imperative to avoid forcing administrators to deal with a new person for every information request they may have. A long-term relationship is clearly called for, allowing the librarian the opportunity to learn the terms and concepts of the client and to understand thoroughly that person's typical information needs as well as the kind and level of response that will meet them. This implies that each librarian should work only with a small number of administrators.

5. Confidentiality. This is an absolutely critical issue because of the multiplicity of roles both parties could have. The kind of confidentiality issues that surface will tend to be different from standard "reference transaction" confidentiality which bears upon any user's right to privacy; these issues will bear more upon internal administrative confidentiality. We suggest that each library use existing codes of library professional ethics ${ }^{8}$ and, in addition, develop clear local guidelines for handling issues of administrative confidentiality.

6. Sensing the real need. Apart from the overt request, it will often be possible, just by listening carefully to what a timepressed administrator talks about, to pick up other leads that might be the subject of the librarian's subsequent efforts. For example, in a meeting in which the administrator conveys a straightforward request for information about enrollment trends, 
she or he might keep coming back to the thought that more campus coordination of information resources is needed, and that the campus' institutional research results are not being disseminated satisfactorily to the deans or department chairs. Followup recommendations from the librarian on ways to strengthen the institution's information dissemination channels could be extremely helpful. Taking notes on the administrator's whole response, not merely on the overt request for information, is of inestimable value.

7. Type of questions. Will the questions that can effectively be handled by such a service prove to be self-selecting? In the pilot project, they were almost all at one end of the spectrum-the long-term, complex issue, demanding study and eventual resolution in the form of a new campus position, regulation, or policy. Conspicuous by its absence was the short-term information need, where certain key facts and figures are required to meet a deadline "this afternoon." In terms of an acceptable response time, "three weeks" was frequent during this test; "three hours" was never encountered. Is such self-selection occurring because of the administrator's prior conception of what libraries and librarians are capable of, or "good for?" Is it because the implicit orientation of the Chico test created analogies with scholarly information-seeking (i.e., the research model)?

One perfectly legitimate reason why administrators do not appear to need the library to handle the short-deadline questions is that they, or their immediate support staff, can quickly find the answers themselves. Every office engaged in academic administration keeps a set of indispensable tools of the trade on the shelf; these are, in effect, the ready-reference sources for higher education administration, and will provide answers to a large percentage of the daily need for names, numbers, facts and figures.

8. Is such service size-dependent? That is, will it prove unworkable on large campuses, the one having thirty or forty thousand students? Assuming that the librarians performing the service can only succeed by limiting their spans of service to a few administrators, and assuming also that the number of available librarians is fairly small, is this tantamount to saying that a support service for academic administrators is feasible only on a small, or at most a medium-sized, campus?

Obviously we may anticipate that the larger the campus, the larger (in most cases) the library and staff. But we know too that beyond certain basic minima, library strength does not steadily increase along with geometric or even exponential increases in the size of the student or administrator population. Those who study physician or attorney distribution speak in terms of there being one physician or attorney for every $x$ thousand people in a given area-so far, there appears to be no real discussion of, much less agreement on, the need for one librarian per $x$ faculty or administrators, although ACRL's Formula B for college libraries' does endeavor to link the size of a library's staff to the size of the student FTE and of the collection.

One approach would be to extend the number of administrators each librarian covers and provide assistance for, or diversion of, some of the other tasks for which the librarian is responsible (in other words, look for ways to cut down the amount of time a librarian spends on marginally professional tasks). Another approach would be to limit arbitrarily the other variable, namely the number of administrators who are considered eligible. Instead of extending the service to the level of department chairs, stop at deansa tricky proposition, given the indications of high value that those who have been exposed to this type of intensive personal information support place upon it. The library is in effect saying "we only have a staff large enough to serve this many administrators." But it may make the difference between starting a service and not starting one.

\section{CONCLUSION}

At the beginning of this paper, we hypothesized that a client-centered library/ information support service for administrators would provide benefits to both the academic library and its parent institution. We believe that this working hypothesis 
was amply validated by the test and that similar results could be expected by most academic libraries embarking upon such a service. For the amount of time, money, and effort expended, the test was an unqualified success at CSU-Chico. It seems to have provided useful information to top administrators, to have helped specifically in positively influencing administrators' perceptions about the library and the role of the librarian, and to have contributed to improving the long-term climate of support for the library. We believe that further research and testing by other librarians could help answer unresolved questions such as:

- Assuming that the library can provide such a service, how far through the administrative structure should that service extend, and what are the limits (if any) to the librarian's ability to adapt the role of the library to include that of information support agency for academic administrators?
- What are the major determinants of that role: librarian's time? library funding? library service philosophy? administrators' expectations of library and librarians' capabilities?

- Can such a service work at a very large university or college, which may have a very different ratio of administrators to librarians than its smaller neighbor?

- On what types of information sources do academic administrators rely most heavily in their work? What precisely is the role of the "working collection"?

- Can or should academic librarians add a regular alerting service ("SDI") to the answering of one-time questions, as is often done to handle the permanent or long-term interests of researchers?

For the reasons discussed throughout this paper, we would strongly encourage other academic librarians to begin an administrative support service, at least in a test mode with a view to creating a permanent service for campus administrators.

\section{REFERENCES AND NOTES}

1. Charles Martell, The Client-Centered Academic Library (Westport, Conn.: Greenwood, 1983).

2. Mary B. Cassata and Roger C. Palmer, Proposal for an Information Service for University Administrators: Office of Specialized Services-Implementation (SUNY-Buffalo Libraries, 1973). ED 077540.

3. A notable Supreme Court decision (Yeshiva, 1980) found the faculty at one institution to be "the management" of the university, and thus ineligible to organize into a bargaining unit.

4. There are at least eight different roles that a faculty member may adopt, all of which arguably have different information needs and different information-seeking patterns: teacher, researcher, leader (i.e., manager) of a research team, student advisor, administrator, consultant, faculty employee (with faculty committee assignments), and private citizen (the academic library often functions as their public library).

5. Rebecca Kellogg, "From the President," RQ 25:9-10 (Fall 1985).

6. Rebecca Kellogg, "Beliefs and Realities," College \& Research Libraries News 47:492-96 (Sept. 1986).

7. Peter G. Watson, "Information for Administrators," College \& Research Libraries News 49:5-6 (Jan. 1988).

8. "A Commitment to Information Services: Developmental Guidelines." Prepared by the ALA/RASD Evaluation of Reference and Adult Services Committee, 1979, rev. 1985, sect. 6.3.

9. "Standards for College Libraries, 1985." Prepared by the College Library Standards Committee of ACRL. College \& Research Libraries News 46:247 (May 1985).

\section{APPENDIX A: SAMPLE LOG SHEET}

$\mathrm{PW}=$ Peter Watson

Libn $=$ Other Librarian
$\mathrm{LA}=$ Library Assistant

$\mathrm{SA}=$ Student Assistant 
APPENDIX 1. Sample Log-Sheet Ablreviations: PW = Peter Watson L LA = I.ibrary Assistant

I ilon = Other Librarian $S A=$ Student Assistant

\begin{tabular}{|c|c|c|c|c|c|c|c|}
\hline 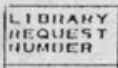 & 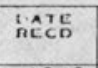 & LiCAB & SUUJECT OF THE REQUEST & AกTE & SOUHCE OF ANSWER FON HEQUEST & $\begin{array}{l}\text { TIME } \\
\text { Spinit } \\
\text { Mins. }\end{array}$ & $\begin{array}{l}\text { SENT TOO Ä(1) DATE ON } \\
\text { ADDITIOMAL COMMENTS }\end{array}$ \\
\hline 1. & $\begin{array}{l}1986 \\
9 / 26 \\
\end{array}$ & $10 / 3$ & $\begin{array}{l}\text { Salary \& compensation } \\
\text { ranges \& criteria- } \\
\text { selected professions }\end{array}$ & $9 / 30$ & $\begin{array}{l}\text { Publications of the Bureau } \\
\text { of Labor Stats }\end{array}$ & $\begin{array}{l}90 \\
30 \\
\end{array}$ & $\begin{array}{l}\text { Searching } \\
\text { photocopying }\end{array}$ \\
\hline 2. & $9 / 30$ & $10 / 24$ & $\begin{array}{l}\text { Calif. Code requirements } \\
\text { for CSU graduation }\end{array}$ & $10 / 20$ & CSU Campus catalogs & $\begin{array}{l}30 \\
90 \\
\end{array}$ & $\begin{array}{l}\text { PW Checking code \& catalogs } \\
\text { SA look-up \& copy }\end{array}$ \\
\hline 3. & $10 / 16$ & - & $\begin{array}{l}\text { Textbooks in field of } \\
\text { Business Law }\end{array}$ & $10 / 23$ & BIP Online; ERIC & $\begin{array}{l}10 \\
10 \\
\end{array}$ & $\begin{array}{l}\text { Libn. Annotated } \\
\text { PW } \\
\text { print-out sent }\end{array}$ \\
\hline 4. & $10 / 16$ & - & $\begin{array}{l}\text { Textbooks in field of } \\
\text { International Law }\end{array}$ & $10 / 23$ & BIP Online; ERIC & $\begin{array}{l}10 \\
10 \\
\end{array}$ & $\begin{array}{ll}\text { Libn. } & \text { Annotated } \\
\text { PW } & \text { print-out sent } \\
\end{array}$ \\
\hline 5. & $10 / 16$ & - & $\begin{array}{l}\text { Textbooks in field of } \\
\text { Corpordtion Law }\end{array}$ & $10 / 23$ & BIP Online; ERIC & $\begin{array}{l}10 \\
10 \\
\end{array}$ & $\begin{array}{ll}\text { Libn. } & \text { Annotated } \\
\text { PW } & \text { print-out sent } \\
\end{array}$ \\
\hline 6. & $10 / 16$ & - & $\begin{array}{l}\text { Undergrad. programs } \\
\text { in Polymer Sci/Tech. }\end{array}$ & $10 / 23$ & ERIC & $\begin{array}{l}10 \\
10 \\
\end{array}$ & $\begin{array}{l}\text { Libn. Annotated } \\
\text { PW } \\
\end{array}$ \\
\hline 7. & $10 / 16$ & - & $\begin{array}{l}\text { Dissenination of } \\
\text { institutiond research }\end{array}$ & $10 / 27$ & ERIC & $\begin{array}{l}10 \\
20\end{array}$ & $\begin{array}{ll}\text { PW } & \text { Sent annotated } \\
\text { L.A } & \text { print-out \& } 2 \text { copies } \\
\text { SA } & \text { from MF }\end{array}$ \\
\hline 8. & $10 / 16$ & - & $\begin{array}{l}\text { Alternatives to the } \\
3 \text {-unit course }\end{array}$ & $10 / 24$ & ERIC & $\begin{array}{l}10 \\
20\end{array}$ & $\begin{aligned} & \text { PW } \text { Sent annotated } \\
& \text { print-out } \\
& 4 \text { articles copied } \\
&\end{aligned}$ \\
\hline 9. & $10 / 16$ & - & $\begin{array}{l}\text { Academic/Corpordte } \\
\text { relationships - public } \\
\text { universities }\end{array}$ & $12 / 15$ & ERIC & 15 & $\begin{array}{l}87 \text { citations; } \\
\text { patron wanted all }\end{array}$ \\
\hline 10. & $11 / 4$ & $12 / 5$ & $\begin{array}{l}\text { Summer programs for } \\
\text { ndtive Am. Students }\end{array}$ & $11 / 11$ & ERIC & 10 & $\begin{array}{l}\text { Sent annotated } \\
\text { print-outs } \\
2 \text { articles copied }\end{array}$ \\
\hline 11. & $11 / 4$ & $12 / 5$ & $\begin{array}{l}\text { Methudology for studying } \\
\text { special students }\end{array}$ & $11 / 14$ & ERIC & 30 & $\begin{array}{l}\text { Annotated } \\
\text { print-out sent }\end{array}$ \\
\hline 12. & $11 / 4$ & - & $\begin{array}{l}\text { Microcomputer use by } \\
\text { Stud. Aft. professionals }\end{array}$ & $11 / 21$ & ERIC & 10 & $\begin{array}{l}\text { Annotated } \\
\text { print-out sent }\end{array}$ \\
\hline 13. & $\frac{1987}{3 / 30}$ & $4 / 7$ & $\begin{array}{l}\text { Csu chico's first } \\
\text { budget (for centennial) }\end{array}$ & $4 / 3$ & $\begin{array}{l}\text { University archives } \\
\text { 1908/09 first available year }\end{array}$ & $\begin{array}{l}10 \\
20\end{array}$ & $\begin{array}{l}\text { Retrieval } \\
\text { (adding monthly } \\
\text { accounts!) telephoned }\end{array}$ \\
\hline
\end{tabular}

